\title{
The Validity of Flipped Classroom Learning Videos on the Material of Parabolic Motion
}

\author{
Arman La Aca ${ }^{1}$, Dwi Sulisworo ${ }^{2, *}$, Guntur Maruto ${ }^{3}$ \\ ${ }^{1}$ Department of Physics Education, Ahmad Dahlan University, Indonesia \\ ${ }^{2}$ Graduate School, Ahmad Dahlan University, Indonesia \\ ${ }^{3}$ Department of Physics, Gadjah Mada University, Indonesia
}

Received May 6, 2020 ; Revised June 17, 2020; Accepted July 5, 2020

\section{Cite This Paper in the following Citation Styles}

(a): [1] Arman La Aca, Dwi Sulisworo, Guntur Maruto , "The Validity of Flipped Classroom Learning Videos on the Material of Parabolic Motion," Universal Journal of Educational Research, Vol. 8, No. 10, pp. 4863 - 4869, 2020. DOI: 10.13189/ujer.2020.081058.

(b): Arman La Aca, Dwi Sulisworo, Guntur Maruto (2020). The Validity of Flipped Classroom Learning Videos on the Material of Parabolic Motion. Universal Journal of Educational Research, 8(10), 4863 - 4869. DOI: 10.13189/ujer.2020.081058.

Copyright $\odot 2020$ by authors, all rights reserved. Authors agree that this article remains permanently open access under the terms of the Creative Commons Attribution License 4.0 International License

\begin{abstract}
This research aimed to discover the validity and the feasibility of the learning videos on parabolic motion materials. These videos are provided for the flipped classroom activity. The output of this research is the product of learning videos that are valid and feasible used as learning media. This research develops with the ADDIE model using two videos, a video of physics concept analysis in daily life, and a video of teacher's explanation in the form of light board-based video. The validity average of learning videos from material experts is $94.44 \%$ for 1st-learning video, and $93.06 \%$ for 2nd-learning video. Besides, the validity average from media experts is $91.57 \%$ for 1st-learning video, and $90.19 \%$ for 2nd-learning video. Therefore, the validity is in the very valid category. The percentage average of students' responses towards the 1st-learning video is $90.02 \%$; the 2nd-learning video is $98.37 \%$. Hence, the student's responses to learning videos are categorized as very feasible. Based on validator and students' response evaluation results, learning videos are valid and feasible for learning media. This study can be a reference to produce effective and efficient learning media. The limitation of this research is that the effectiveness of the learning video had not been tested.
\end{abstract}

Keywords Validity, Learning Video, Flipped Classroom, Lightboard, Parabolic Motion

\section{Introduction}

Students often find problems in the learning process, in case not understand the materials from the teacher; as a result, they find difficulties in finishing the teacher's assignments. This condition happened due to the conventional method (lecture method) used by the teacher in explaining the subject in the classroom and used textbooks only as learning media. Learning becomes inflexible, dull, and passive. Whereas, 21st-century learning requires the implementation of student-centered learning [1,2], not teacher-centered learning. Therefore, the implementation of the 21st-century learning needs the appropriate learning approaches and media.

One of the learning approaches used in the education of the 21st century is the flipped classroom. A Flipped classroom is a learning model that flips teaching techniques in the class, which is traditionally done in the classroom, done at home, and what is traditionally did as homework [3-8]. According to [9-11], a flipped classroom is a learning model that combines technology to encourage students to become active and efficient that can develop student-student interaction and student-teacher interaction in participating in problem-solving actively.

This approach develops students' independence. Students have to study the materials in the forms of video at home before the classroom activity start [12-15], write all the question they have, make a summary $[5,16]$, and 
answer questions in the video. When the class begins, they are involved in solving problems and participating in discussions with classmates or the teacher collaboratively and actively. At the same time, the teacher answers students' questions, gives assistance, guidance, and feedback [11,15-17].

Parabolic motion is one of the physics materials used in flipped classroom learning. In daily life, students may often see examples of parabolic motion. However, since they occur in a short time, it is hard to observe them. Consequently, the teacher can use learning media. The implementation of a flipped classroom also highly requires learning media since it is an essential element in the learning process. One of the learning media used in flipped classroom learning is a learning video. A learning video is one of the audiovisual media forms. Once students have to watch a learning video before they study, they can get a tangible and systematic description of the concept being studied. It increases student's learning interest and motivates them in the learning process. Students can also understand learning materials better [16].

Supporting the facilities of information and communication technology, schools usually provide computer laboratories, and generally, parents give their children a smartphone or even a laptop. Students typically use laptops and smartphones for playing games and social media, which can disturb their study. On the other hand, technology can also utilize learning as sharing tools and playing learning videos.

This paper aimed to find out the validity of learning videos on the material of parabolic motion. Previous research has explained the development of animation videos for flipped classroom model on the material of dynamic motion by using Powtoon software [2]. Another studied in the development of learning media on the material of heat for seventh-grade students. The learning video was about a simple experiment in daily life [18]. The two developed videos are valid and feasible, used as learning media. The product of this research (learning videos) would be the learning resources for flipped classroom implementation.

The difference from previous research since this research has two learning videos developed; those are videos of physics concept analysis in daily life and light board-based learning video. Learning videos developed expected will give a better understanding of the physics concepts, ease the students in understanding the implementation of the physics concepts and problem-solving methods. Therefore, students can finish assignments given by the teacher well. So that learning videos developed can be utilized in learning, they need to have qualities. One of the criteria for quality learning videos is having high validity.

\section{Methods}

This investigation was Research and Development (R\&D) using an ADDIE model [19]. ADDIE stands for Analysis, Design, Development, Implementation, and Evaluation. The development phases of learning videos (lightboard-based video) by using ADDIE development model were ((1) analysis, to obtain the need description in physics learning, (2) design, to make the initial designs of learning videos, (3) development, in this phase, the designs of learning videos realized into products, (4) implementation, the experts and the physics teacher did the validity test by using questionnaires, the learning videos revised and tested to students and, (5) evaluation, in this phase, an evaluation did to find out the validity of the learning videos developed. The result would be used in the flipped classroom implementation.

Lightboard is a tool for creating video learning. It is a transparent glass with LED lights. The teacher faces the camera (in the same direction as the students' position) and writes on the board. This activity is recorded at the same time. The teacher faces the students, and the writing is glowing. Bright light-emitting diode lights (LEDs) are placed along the bottom and the top of the glass to reflect light on the glass panel. When the teacher writes or draws on the Lightboard with a colored marker, the LED light causes the ink marker to light up (illuminated) [20].

The subjects in this research were six experts (two material experts, two media experts, and two physics teachers). The response form was collected from 33 tenth-grade students. They study at a public senior high school in Sorong city, West Papua, Indonesia. The data collected was quantitative data obtained by using questionnaires as the research instrument.

The questionnaire for validation was filled in by experts and teachers. The results of this questionnaire are processed to see the average and its deviation as a basis for determining the level of product validation (See Table 1 and Table 2 for all criteria). The data analysis phases were:

1. checking the completeness of questionnaire sheets and data filled out by the respondents,

2. calculating the percentage score obtained from each aspect,

3. calculating the average of the score percentage obtained from each respondent,

4. calculating the average of the score percentage of all respondents,

5. converting the quantitative data into qualitative data with five scales, as shown in Table 1, and comparing the percentage average obtained by using the criteria.

Learning videos developed are stated valid and feasible as learning media if the average score percentage obtained is more than $70 \%$ [21]. Table 1 shows the validity and feasibility criteria for learning videos as learning media. 
Table 1. The Learning Video Validity and Feasibility Criteria

\begin{tabular}{|c|c|}
\hline Interval & Criteria \\
\hline $\mathrm{x} \geq 85 \%$ & Very valid/ Very feasible \\
\hline $70 \% \leq \mathrm{x}<80 \%$ & Valid/ Feasible \\
\hline $55 \% \leq \mathrm{x}<70 \%$ & Fairly valid/ Fairly feasible \\
\hline $40 \% \leq \mathrm{x}<55 \%$ & Less valid/ Less feasible \\
\hline $\mathrm{x} \leq 40 \%$ & Invalid/ Poor \\
\hline
\end{tabular}

\section{Result}

\subsection{Analysis and Design}

Observations and interviews with the teacher revealed that the teacher often used the conventional (lecture) method and used books only as learning media. The learning process was relatively inflexible, boring, and passive. Therefore, it needed innovation to make learning more active, attractive, and fun, so that students can get a better understanding of the subject. One of the materials that can be used in this model is parabolic motion. It is a physics concept that is quite hard to be explained in more real since it occurs very fast.

Based on the functions above, the learning videos developed were divided into two, first was a basketball game video that was analyzed to explain the concept of parabolic motion in real activity to students. The second was a lightboard-based learning video by using a glass chalkboard pumped full of light that enabled the teacher to explain the formula derivation and the examples of questions, and give exercises. It is a similar use of whiteboard video in the classroom.

In the designing phase, researchers designed and divided the parabolic motion materials to discuss in the first and second learning videos. The first learning video explained the concept of parabolic motion, such as what is parabolic motion, scales that affect parabolic motion, and characteristics of parabolic motion. The second learning video discussed the formula derivation, the examples of the application in the questions, and exercises. Next, researchers arranged the scenario, determined the duration, and prepared the equipment to make the video. The equipment was a camera, tripod, lighting devices, clip-on, black and green backdrop cloth, light board, neon marker, and eraser.

\subsection{Development}

The development phase was the phase of learning video production. Learning videos were produced based on the scenarios. Figure 1 and Figure 2 show the production process of learning video. After that, Adobe Premiere Pro
CC 2018 used to edit the learning video, as shown in Figure 3 and Figure 4.

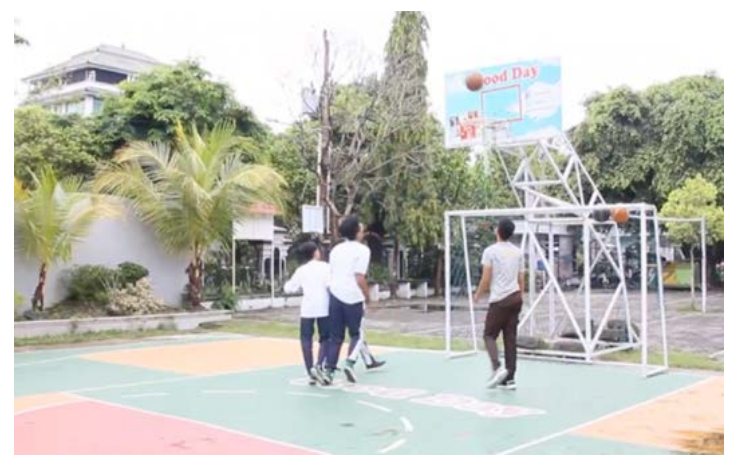

Figure 1. The production of the first learning video

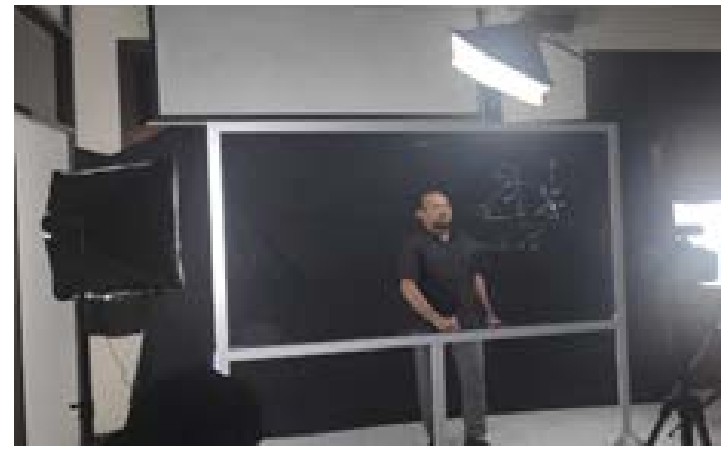

Figure 2. The production of the second learning video

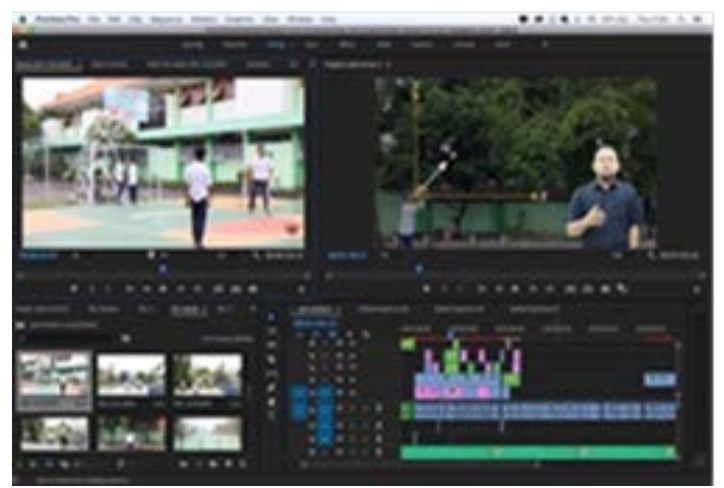

Figure 3. Editing of the first learning video

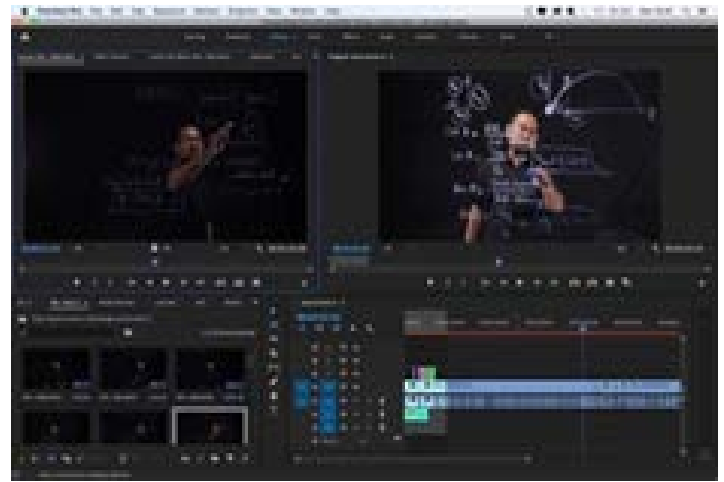

Figure 4. Editing of the second learning video 


\subsection{Implementation and Evaluation}

The validity of the two learning videos developed tested by a material expert, a media expert, and a physics teacher. The material validation was done by a material expert (Material Expert 1 and Material Expert 2) and a physics teacher (Material Expert 3) while the media validity did by a media expert (Media Expert 1 and Media Expert 2) and a physics teacher (Media Expert 3). The material evaluation aspects were relevance, material organization, and language. The aspects of media evaluated were the effects of learning, media creation, and audiovisual display. Table 2 shows the calculation for material validity. Table 3 shows the calculation for media validity.

Table 2. The Material Validity Calculation

\begin{tabular}{|c|c|c|c|c|c|c|}
\hline \multirow{2}{*}{} & \multicolumn{3}{|c|}{ 1nd-learning video } & \multicolumn{3}{c|}{ 2nd-learning video } \\
\cline { 2 - 7 } & \multicolumn{3}{|c|}{ Material Expert } & \multicolumn{3}{c|}{ Material Expert } \\
\cline { 2 - 7 } & 1 & 2 & 3 & 1 & 2 & 3 \\
\hline \multicolumn{7}{|c|}{ Relevance (2 items) } \\
\hline Total Score & 8 & 8 & 8 & 8 & 8 & 8 \\
\hline Max Score & 8 & 8 & 8 & 8 & 8 & 8 \\
\hline Percentage & 100 & 100 & 100 & 100 & 100 & 100 \\
\hline \multicolumn{7}{|c|}{ Object Organization (6 items) } \\
\hline Total Score & 21 & 20 & 21 & 19 & 20 & 20 \\
\hline Max Score & 24 & 24 & 24 & 24 & 24 & 24 \\
\hline Percentage & 87.50 & 83.33 & 87.50 & 79.17 & 83.33 & 83.33 \\
\hline & 11 & 12 & 12 & 11 & 12 & 12 \\
\hline Total Score & 11 & 12 & 12 & 12 & 12 & 12 \\
\hline Max Score & 12 & 12 & 100 & 91.67 & 100 & 100 \\
\hline Percentage & 91.67 & 100 & 100 & \\
\hline $\begin{array}{c}\text { Aspects' } \\
\text { Average }\end{array}$ & 93.06 & 94.44 & 95.83 & 90.28 & 94.44 & 94.44 \\
\hline $\begin{array}{c}\text { Experts' } \\
\text { Average }\end{array}$ & 94.44 & & & 93.06 & & \\
\hline
\end{tabular}

Table 3. The Media Validity Calculation

\begin{tabular}{|c|c|c|c|c|c|c|}
\hline \multirow{2}{*}{} & \multicolumn{3}{|c|}{ 1nd-learning video } & \multicolumn{3}{c|}{ 2nd-learning video } \\
\cline { 2 - 7 } & \multicolumn{7}{|c|}{ Media Expert } & \multicolumn{3}{c|}{ Media Expert } \\
\cline { 2 - 7 } & 1 & 2 & 3 & 1 & 2 & 3 \\
\hline Total Score & 24 & 23 & 24 & 23 & 23 & 23 \\
\hline Max Score & 24 & 24 & 24 & 24 & 24 & 24 \\
\hline Percentage & 100 & 95.83 & 100 & 95.83 & 95.83 & 95.83 \\
\hline \multicolumn{7}{|c|}{ Media Creation (5 items) } \\
\hline Total Score & 18 & 18 & 18 & 18 & 18 & 18 \\
\hline Max Score & 20 & 20 & 20 & 20 & 20 & 20 \\
\hline Percentage & 90.00 & 90.00 & 90.00 & 90.00 & 90.00 & 90.00 \\
\hline \multicolumn{7}{|c|}{ Audiovisual display (6 items) } \\
\hline Total Score & 21 & 20 & 21 & 20 & 20 & 21 \\
\hline Max Score & 24 & 24 & 24 & 24 & 24 & 24 \\
\hline Percentage & 87.50 & 83.33 & 87.50 & 83.33 & 83.33 & 87.50 \\
\hline $\begin{array}{c}\text { Aspects' } \\
\text { Average }\end{array}$ & 92.50 & 89.72 & 92.50 & 89.72 & 89.72 & 91.11 \\
\hline $\begin{array}{c}\text { Experts' } \\
\text { Average }\end{array}$ & 91.57 & & & 90.19 & & \\
\hline
\end{tabular}

Based on Table 2, the average of learning video validity from material validators is $94.44 \%$ for 1 st-learning video, and $93.06 \%$ for 2nd-learning video. Refer to Table 1, these values are in Very Valid category.

Based on Table 3, the average of learning video validity from media validators is $91.57 \%$ for 1 st-learning video, and $90.19 \%$ for 2nd-learning video. Refer to Table 1, these values are in Very Valid category.

Therefore, the learning videos on the parabolic motion are stated very validly used as learning media. The suggestion following the validators' recommendations is shown in Table 4.

Table 4. Validators' Recommendation for Learning Video

\begin{tabular}{|c|l|l|}
\hline $\begin{array}{c}\text { Learning } \\
\text { Video }\end{array}$ & \multicolumn{1}{|c|}{$\begin{array}{l}\text { Validators' } \\
\text { Recommendation }\end{array}$} & \multicolumn{1}{|c|}{ Revisions } \\
\hline First & $\begin{array}{l}\text { The writing of the word } \\
\text { 'benda' is not } \\
\text { appropriate. } \\
\text { No need to use the } \\
\text { speed indicators to show } \\
\text { the increase or the } \\
\text { decrease of the speed. }\end{array}$ & $\begin{array}{l}\text { The word } \\
\text { 'benda' is } \\
\text { replaced with } \\
\text { 'bola'. } \\
\text { Removing } \\
\text { the speed } \\
\text { indicators. }\end{array}$ \\
\hline Second & $\begin{array}{l}\text { Learning video is good } \\
\text { but the clarity of the } \\
\text { writing needs to be } \\
\text { clarified. } \\
\text { Learning video needs to } \\
\text { be divided into several } \\
\text { parts. }\end{array}$ & $\begin{array}{l}\text { The writing } \\
\text { is clarified. } \\
\text { Video is } \\
\text { divided into } \\
\text { several parts }\end{array}$ \\
\hline
\end{tabular}

Based on the recommendations above, researchers revised the two learning videos. After being revised, learning videos were tested to students to find out the students' responses towards the videos. Table 5 shows the result.

The students are given learning videos that have been developed to find out the students' responses on a small scale, next they filled in the questionnaire response or learning media that includes teaching material, learning impact, audiovisual display, and language. Then, the averages score is determined based on these results (See Table 5).

Table 5. Students' responses $(n=33)$

\begin{tabular}{|c|c|c|c|c|}
\hline \multirow{2}{*}{ Aspects } & \multicolumn{3}{|c|}{ Average of respondents (n=33) } \\
\cline { 2 - 5 } & $\begin{array}{c}\text { Total } \\
\text { Score }\end{array}$ & $\begin{array}{c}\text { Max } \\
\text { Score }\end{array}$ & $\%$ & STD \\
\hline \multicolumn{5}{|c|}{ 1st-learning video } \\
\hline Material (6 items) & 21.15 & 24.00 & 88.13 & 0.08 \\
\hline Effect for learning (8 items) & 29.24 & 32.00 & 91.38 & 0.09 \\
\hline Audiovisual display (3 items) & 10.82 & 12.00 & 90.15 & 0.18 \\
\hline Language (3 items) & 10.85 & 12.00 & 90.40 & 0.12 \\
\hline Average of all aspects & & & 90.02 & \\
\hline \multicolumn{5}{|c|}{ 2st-learning video } \\
\hline Material (6 items) & 21.03 & 24.00 & 87.63 & 0.10 \\
\hline Effect for learning (8 items) & 28.82 & 32.00 & 90.06 & 0.11 \\
\hline Audiovisual display (3 items) & 10.9 & 12.00 & 91.16 & 0.14 \\
\hline Language (3 items) & 10.6 & 12.00 & 88.64 & 0.16 \\
\hline Average of all aspects & & & 98.37 & \\
\hline
\end{tabular}


Based on Table 5, the percentage average of students' responses towards the 1st-learning video is $90.02 \%$, and the 2nd-learning video is $98.37 \%$. These values are in a very feasible category (See Table 1). Qualitatively, it concluded that the learning videos on the parabolic motion are feasible to be used as learning media.

In line with the evaluation result from the material expert, the media expert, the physics teacher, and the students' responses, it concluded that the learning videos are valid and feasible used as learning media.

\section{Discussions}

In $[22,23]$, they have researched the length of videos that students should watch. It showed that students watching a less than 6 minutes long video was almost $100 \%$, a 9 to 12 minutes long video was about $50 \%$, a 12 to 40 minutes long video was $20 \%$. Therefore, making a video of more than 6-9 minutes long may be wasteful. [23] stated that a shorter learning video is more attractive than a longer one. Students' participation in a video significantly decreases after 6 minutes. Researchers made the first learning video with a length of about 6 minutes, and researchers also divided the second learning video that was about 50 minutes long into seven parts of 6-9 minutes long.

Figure 4 shows that the first learning video is better than the second in terms of the material, effects for learning, and language. The first learning video contains an analysis and explanation of basketball movements used by students. By using the language style and audiovisual, students are engaged to watch the video and motivate them to learn about it. As a result, it gives the concept of understanding to students.

The second learning video is better than the first one in terms of audiovisual display. This learning video is a new thing for students, in the form of teachers' explanations on the lightboard. In reference [24,25], mention that lightboard is a glass chalkboard pumped full of light. The lighting is from a LED strip that is edge light around the glass board, the neon marker used to write, and lighting devices. The light bounces around inside the glass until the light hits the neon marker writing and exits the glass through the marker writing. It makes the writing pop out against the black backdrop. The teacher explains the formula derivation, the use, and the application on the problems, examples of problems in daily life, then gives exercises that are divided into some videos.

The two learning videos complete each other. On one side, the learning video from daily activities that are analyzed can make students understand the physics concept more real [16]. On another side, in reference [20], lightboard-based learning can give students an understanding of the formula derivation and examples of problem application in daily life, making the teacher feel comfortable teaching using a whiteboard in the classroom.
The teacher could not ensure whether the students genuinely watch the learning videos or the learning videos also create one-way communication that students could only watch and could not directly ask the teacher if they find difficulties. Response to these problems, when before the learning videos played, the teacher gives instructions to students to pause the video while writing questions, rewind or fast-forward while writing a summary of the materials, and answering the questions from the video.

At the beginning of in-class learning, the teacher can ask students to submit the result of the summary, give quizzes related to the materials in the learning videos and answer questions from students related to the materials $[5,16]$. Therefore, the teacher can ensure that students watch the learning videos have given, and the communication can be built from teacher to student and student to student on the classroom learning. The classroom learning can be alive along with the increase of students' participation and activities in the classroom learning, so students can be more comfortable and confident because they have prepared well before in-class learning [26-30].

The teacher acts as the facilitator, whereas the teacher answers the students' questions, assists and guides students in problem-solving activities collaboratively such as experiments, presentations, finishing application questions in daily life, interactive discussion, and giving feedback [11,15-17]. Hence, it enables students to develop more critical thinking skills [8,29,31]. Learning becomes Student-centered [1,2,7]. Students' independence developed through the learning video [13-15]. The students get easier in understanding materials since the videos can be watched repeatedly [31,32].

\section{Conclusions}

The need analysis result shows that the learning media in the form of video is following the character of students and learning objectives. The design made using a light board to explain the activity. In developing this learning media, preliminary media experts, material experts, and physics teachers did the validation. The improvement results from this validation became a design that was tested on a small group to determine student responses. From the results of a thorough evaluation taking into account the validation of experts, teachers, and student responses, it implies that this media is appropriate for use. In the next stage of the study, the effectiveness and practicality of this learning medium will improve student learning achievement.

\section{Acknowledgments}

This research was funded by the Indonesian Ministry of Education and Culture through the Graduate Research Grant for the Year 2020. 


\section{REFERENCES}

[1] T. S. Toh, K. A. Tengah, M. Shahrill, A. Tan, \& E. Leong. The Flipped Classroom Strategy: The Effect of Implementation at The Elementary School Level Mathematics Lessons, Proceeding of The3rd International Conference on Education, 186-197, 2017.

[2] K. Basriyah, D. Sulisworo. Pengembangan Video Animasi Berbasis Powtoon Untuk Model Pembelajaran Flipped Classroom pada Materi Termodinamika, Seminar Nasional Edusaintek FMIPA UNIMUS 2018, 152-156, 2018.

[3] J. Bergmann, A. Sams. Flip your Classroom: Every Student in Every Class Every Day, OR: International Society for Technology in Education, Eugene, 2012.

[4] A. Roehl, S. L. Reddy, G. J. Shannon. The flipped classroom: an opportunity to engage millennial students through active learning strategies, Journal of Family and Consumer Sciences, Vol. 105, No. 2, 44-49, 2013.

[5] J. Nouri. The flipped classroom: for active, effective and increased learning - especially for low achievers, International Journal of Education Technology in Higher Education, Vol. 13, No. 33, 2016.

[6] S. J. Delozier, M. G. Rhodes. Flipped classroom: a review of key ideas and recommendations for practice, Journal of Education Psychology, Vol. 29, 141-151, 2017.

[7] D. Sulisworo, K. Basriyah, L. Sari, M. Toifur. Comparing the effectiveness of flipped classroom and online learning on improving critical thinking skills in high school physics learning, Advance in Social Science, Educational and Humanities Research, Vol. 349, 645-649, 2019.

[8] S. Koes-H, F. S. Putri, E. Purwaningsih, A. Y. Salim. The Influence of Flipped Classroom in Inquiry Learning to Student's Critical Thinking Skills in Impulse and Momentum. The 3rd International Conference on Mathematics and Sciences Education (ICoMSE) 2019, AIP Conference Proceedings, 050008-1-05008-6, 2020.

[9] A. M. Al-Zahrani. From passive to active: the impact of the flipped classroom through social learning platforms on higher education students' creative thinking, British Journal of Educational Technology, Vol. 46, No. 6, 1133-1148, 2015.

[10] Wolff, L. C., \& Chan, J. Flipped Classroom for Legal Education, Springer, Singapore, 2016.

[11] D. G. Purwitha. Model pembelajaran flipped classroom sebagai pembelajaran inovatif abad 21, ADI WIDYA: Jurnal Pendidikan Dasar, Fakultas Dharma Acarya, Institut Hindu Dharma Negeri Denpasar, Vol. 5, No. 1, 49-55, 2020.

[12] H. N. Mok. Teaching tip: the flipped classroom, Journal of Information System Education, Vol. 25, No. 1, 7-11, 2014.

[13] P. Lin, H. Chen. The effect of flipped classroom on learning effectiveness: using learning satisfaction as the mediator, World Transactions on Engeneering and Technology Education (WIETE), Vol. 14, No. 2, 231-244, 2016.
[14] L. P. Sari, M. Handika, E. Rosita, M. Sari, B. S. Anggoro, F. G. Putra. The flipped classroom strategy using learning video: applied toward the ability to understand mathematical concepts, Journal of Physics: Conference Series, vol. 1155, 2019.

[15] F. J. Robinson, P. M. Reeves, H. L. Caines, C. D. Grandi. Using open-source videos to flip a first-year college physics class, Journal of Science Education and Technology, Vol. 29, 283-293, 2020.

[16] X. Wei, I. Cheng, N. Chen, X. Yang, Y. Liu, Y. Dong, X. Zhai, Kinshuk. Effect of the flipped classroom on the mathematics performance of middle school students, Educational Technology Research and Development, 2020.

[17] C. R. Philips, J. E. Trainor, J. E. Millenial Students and The Flipped Classroom, Proceeding of ASBBS, Vol. 21, No. 1, 519-530, 2014.

[18] A. Ulyana, Z. Abidin, A. Husna. Pengembangan video pembelajaran kalor untuk siswa kelas vii, Jurnal Inovasi Teknologi Pembelajaran (JINOTEP), Vol. 5, No. 2, 81-86, 2019.

[19] E. Mulyatiningsih. Metode Penelitian Terapan Bidang Pendidikan, Alfabeta, Bandung: Alfabeta, 2011.

[20] E. S. Skibinski, W. J. DeBenedetti, A. G. Ortoll-Bloch and M. A. Hines. (2015). A blackboard for the 21st century: An inexpensive light board projection system for classroom use.Chemical Education, Vol 92, No. 10, 1754-1756.

[21] S. Arikunto. Dasar-dasar Evaluasi Pendidikan, PT Bumi Aksara, Jakarta, 2013.

[22] C. J. Brame. Effective Educational Videos: Principles and Guidelines for Maximizing Student Learning from Video Content, CBE-Life Sciences Education, vol. 15, no. 4, 1-6, 2016.

[23] P. J. Guo, J. Kim, J, R. Robin. How Video Production Affects Student Engagement: an Empirical Study of MOOC Videos, L@S’14 Proceedings of the First ACM Conference on Learning at Scale, New York: ACM, 41-50, 2014.

[24] Flippedlearning.org, How to Make a Lightboard for Less Than \$100 (Step-by-Step), With Illustrations), Online available fromhttps://flippedlearning.org/how_to/how-to-m ake-a-lightboard-for-less-than-100/

[25] Lightboard Home, Online available from https://lightboard.info

[26] D. Ramirez, C. Hinojosa, Rodriguez. Advantages and Disadvantages of Flipped Classroom: Stem Students' Perceptions, Iceri 2014: 7Th International Conference of Education, Research and Innovation, 2014.

[27] S. Du, Z. Fu, Y. Wang. The Flipped Classroom Advantages and Challenge, International Conference on Economic Management and Trade Cooperation (EMTC), 17-20, 2014.

[28] M. B. Gilboy, S. Heinerichs, G. Pazzaglia. Enhancing student engagement using the flipped classroom, Journal of Nutrition Education and Behavior, Vol. 47, No. 1, 109-114, 2015.

[29] H. Baytiyeh, M. H. Naja. Students' perceptions of flipped classroom model in an engineering course: a case study, European Journal of Engineering Education, Vol. 42, No. 6, 
1-14, 2016.

[30] V. Betihaves, H. Bridgman, R. Kornhaber, M. Cross. The evidence for 'flipping out': a systematic review of the flipped classroom in nursing education, Nurse Education Today, Vol. 38, 15-21, 2016.

[31] Y. Yelensi, K. Wiyono, N. Andriani, N. Efektivitas penggunaan video pembelajaran materi usaha dan energi berbasis permainan tradisional, Jurnal Pijar MIPA, Vol. 15, No. 1, 1-6, 2020.

[32] Zulherman, A. Pasaribu, K. Wiyono, Saparini, W. Oktori. Pengembangan Video Pembelajaran Berbasis Permainan Tradisional pada Materi Gerak Melingkar, Seminar Nasional Program Studi Pendidikan Fisika FKIP ULM, 54-60, 2019. 